\title{
ERRATUM
}

Jörg B. Schulz

\section{Neuronal pathology in Parkinson's disease}

Published online: 1 March 2005

(C) Springer-Verlag 2005

\section{Cell Tiss Res (2004) 318:135-147}

This article has been withdrawn. We have received the following communication from the author:

"It has been brought to our attention that in our invited review entitled "Neuronal pathology in Parkinson's disease" published in Cell and Tissue Research in October 2004, some passages show overlap or similarities in content to the review published by Dauer and Przedborski in Neuron, September 2003, without citation. We apologize to Drs. Dauer and Przedborski and the readership for this oversight and withdraw our manuscript."

\section{References}

Schulz JB, Falkenburger BH (2004) Neuronal pathology in Parkinson's disease. Cell Tiss Res 318:135-147

Dauer W, Przedborski S (2003) Parkinson's disease: mechanisms and models. Neuron 39:889-909

\footnotetext{
J. B. Schulz $(\bowtie)$

Department of Neurodegeneration and Neurorestoration, DFG Research Center "Molecular Physiology of the Brain" and Center of Neurology, University of Göttingen,

Waldweg 33,

37073 Göttingen, Germany

e-mail: joerg.b.schulz@uni-tuebingen.de

Tel.: +49-7071-2980402

Fax: +49-7071-295260
} 